\title{
TWO NEW NEMATODES, AND NOTES ON NEW FINDINCS OF NEMATODES PARASITIC IN AMPHIBIA ${ }^{1}$
}

\author{
By A. C. Walton \\ Knox College, Galesburg, Ill.
}

Through the courtesy of Dr. M. C. Hall, chief of the zoological division of the United States Bureau of Animal Industry, a number of unnamed nematode parasites of amphibian hosts were recently sent to the writer for examination. Two apparently new species were found, and new host records for several other little-known species were obtained.

The genus Pharyngodon is represented up to this time by only one species that has been reported from an amphibian host: P. batrachiensis Walton, 1929, from a tadpole of Rana pipiens. Female worms taken from adult specimens of Rana pipiens and of $R$. clamitans afford the basis for establishing a second species from amphibian hosts.

PHARYNGODON ARMATUS, new species

Figure $1, a-c$

Specific diagnosis.-Pharyngodon: Male, unknown. Female, short ( $3.5 \mathrm{~mm}$ long), of medium width $(240 \mu)$, and tapering abruptly at the posterior end to a naked spikelike tail. Anterior end shows distinct annulations, which become indistinct caudad; inconspicuous lateral flanges present. Mouth surrounded by three indistinct lips; no buccal cavity or vestibule present, but the pharynx seems to be protected by chitinous plates for a short distance back from the mouth. Excretory pore, like that of the other species from an amphibian host, is opposite, instead of caudad to, the esophageal bulb. Vulva just in front of midregion of body. Eggs a very slightly flattened ovoid with but one distinct terminal plug; segmented (4- or 8-celled) at time of oviposition.

This form resembles $P$. batrachiensis, but in view of the presence of the armored pharynx, the relatively different measurements of important structures, and the difference in the eggs, the variations seem to be of specific importance.

\footnotetext{
1 Contribution No. 42 from the Biological Laboratories of Knox College.
}

No. 2947.-Proceedings U. S. National Museum, Vol. 82, Art. 6 


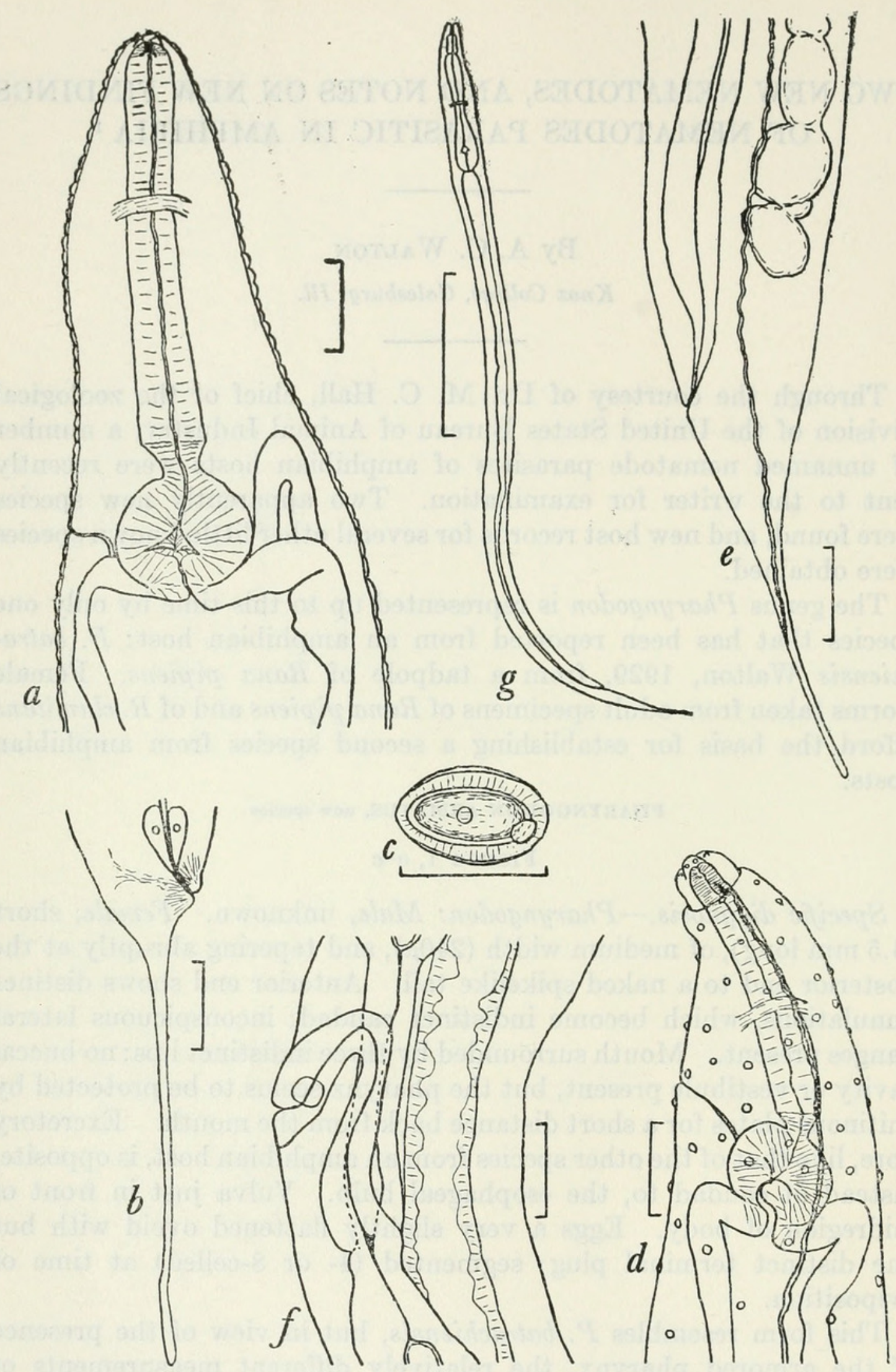

Figure 1.- $a$, Pharyngodon armatus, lateral view of anterior end of female; $b, P$. armatus, lateral view of posterior end of female; $c, P$. armatus, egg; $d$, Oxysomatium punctatum, lateral view of anterior end of female; $e, O$. punctatum, lateral view of posterior end of female; $f, O$. punctatum, vulvar region; $g$, O. punctatum, intra-uterine larva. Scale for all figures equals $0.1 \mathrm{~mm}$ 
The general measurements of the females of the two species are as follows:

\begin{tabular}{|c|c|c|}
\hline Measurement & P. armatus & P. batrachiensis \\
\hline $\begin{array}{l}\text { Total average length } \\
\text { Width at vulva } \\
\text { Esophageal bulb } \\
\text { Distance from nerve ring to lips } \\
\text { Distance from excretory pore to lips } \\
\text { Distance from vulva to lips } \\
\text { Distance from anus to tip of spike } \\
\text { Length of spike } \\
\text { Eggs }\end{array}$ & $\begin{array}{l}3.5 \mathrm{~mm} \\
0.24 \mathrm{~mm} \\
0.28 \mathrm{~mm} \\
0.15 \mathrm{by} 0.15 \mathrm{~mm} \\
0.175 \mathrm{~mm} \\
0.36 \mathrm{~mm} \\
1.5 \mathrm{~mm} \\
0.5 \mathrm{~mm} \\
0.5 \mathrm{~mm} \\
60 \mu \text { by } 100 \mu(4 \text { to } \\
8 \text { celled). }\end{array}$ & $\begin{array}{l}4.2 \mathrm{~mm} . \\
0.36 \mathrm{~mm} . \\
0.56 \mathrm{~mm} \text {. } \\
0.125 \mathrm{by} 0.15 \mathrm{~mm} \text {. } \\
0.165 \mathrm{~mm} . \\
0.61 \mathrm{~mm} . \\
1.8 \mathrm{~mm} . \\
0.9 \mathrm{~mm} \text {. } \\
0.75 \mathrm{~mm} . \\
35 \mu \text { by } 100 \mu \quad(1 \\
\text { celled). }\end{array}$ \\
\hline
\end{tabular}

The name armatus is given because of the armored condition of the anterior end of the esophagus.

Type specimens.-U.S.N.M. Helm. Coll. (Bureau of Animal Industry) No. 27061. From Rana pipiens and R.clamitans, intestine. Collected by Bruce Reynolds, August, 1927, at University, Va.

\section{OXYSOMATIUM PUNCTATUM, new species}

\section{Figure $1, d-g$}

Material collected from Rana vittigera (Los Baños, Philippine Islands) includes female specimens of a species of Oxysomatium, which differs from the other previously described species from the same area in several important features.

Specific diagnosis.-Oxysomatium: Lips distinct and each provided with two papillae. Head definitely separated by a constriction from the rest of the body, a characteristic not found in other species of this genus.

Male, unknown. Female, $3.6 \mathrm{~mm}$ long. Anterior end of worm characterized by the presence of small cuticular bosses, again a specific character for this species only. A very short pharynx precedes the short esophagus, which is followed by a distinct flasklike bulb opening into a greatly dilated intestine. Lateral alae extend from lip region to base of tail spike. Vulva in anterior half of body. Uteri opposed; ovaries amphidelphous. Eggs contained well-defined larvae, some of which are apparently hatched in utero. 
The average measurements as compared with those of the females of the other species recently reported from Philippine amphibian hosts are as follows:

\begin{tabular}{|c|c|c|}
\hline Measurement & o. punctatum & O. ranae \\
\hline Total average length. & $3.6 \mathrm{~mm}$ & $3.8 \mathrm{~mm}$. \\
\hline Width at vulva..... & $0.24 \mathrm{~mm}$ & $0.23 \mathrm{~mm}$. \\
\hline Length of pharynx ..... & $0.045 \mathrm{~mm}$ & $0.03 \mathrm{~mm}$ \\
\hline Length of esophagus... & $0.3 \mathrm{~mm}$ & $0.265 \mathrm{~mm}$. \\
\hline Esophageal bulb & $105 \mu$ by $115 \mu \ldots$ & $65 \mu$ by $85 \mu$. \\
\hline Distance from nerve ring to lips..... & $0.175 \mathrm{~mm}$ & $0.15 \mathrm{~mm}$. \\
\hline Distance from excretory pore to lips. & $0.28 \mathrm{~mm}$ & $0.28 \mathrm{~mm}$. \\
\hline Distance from vulva to lips & $1.6 \mathrm{~mm}$ & $1.8 \mathrm{~mm}$. \\
\hline Distance from anus to tip of tail & $0.45 \mathrm{~mm}$ & $0.23 \mathrm{~mm}$. \\
\hline Eggs $_{-}$ & $62 \mu$ by $105 \mu$ & $56 \mu$ by $76 \mu$. \\
\hline Larvae in utero & $17 \mu$ by $420 \mu \ldots$ & Present. \\
\hline
\end{tabular}

The name punctatum is given because of the characteristic cuticular bosses of the anterior end of the worm.

Type specimens.-U.S.N.M. Helm. Coll. (Bureau of Animal Industry) No. 25874. From Rana vittigera, intestine. Collected by B. Schwartz, 1921-22, Los Baños, Philippine Islands.

\section{RECORDS OF NEMATODES PARASITIC IN AMPHIBIA}

The following list gives the already known species in the collection and indicates their host distribution, many of which are new records:

1. Agamascaris odontocephala Steiner, 1924. From Rana catesbeiana, Virginia, U.S.N.M. Helm. Coll. No. 1569; Rana catesbeiana, Washington, D. C., U.S.N.M. Helm. Coll. No. 7864; Rana clamitans, Washington, D. C., U.S.N.M. Helm. Coll. No. 2298; Rana clamitans and R. sylvatica, Baltimore, Md., U.S.N.M. Helm. Coll. No. 2864; "frogs," Washington, D. C., U.S.N.M. Helm. Coll. No. 2865. The other reported host is Hyla cinerea, United States.

2. Zanclophorus cryptobranchi Walton, 1930. From "Cryptobranchus," Philadelphia, Pa., U.S.N.M. Helm. Coll. No. 15700. The only known host is Cryptobranchus alleganiensis, United States.

3. Aplectana americana Walton, 1929. From Scaphiopus couchii, Texas, U.S.N.M. Helm. Coll. No. 27895. The other reported hosts are Rana catesbeiana, $R$. palustris, and $R$. pipiens, all from the United States.

4. Oxysomaitium ranae Walton, 1931. From "frogs," Los Baños, Philippine Islands. The only identified host is Rana magna (?), Luzon, Philippine Islands.

5. Rhabdias ranae Walton, 1929. From "frogs," Washington, D. C., U.S.N.M. Helm. Coll. No. 26828. Other known hosts are Acris gryllus, Rana halecina, R. palustris, $R$. pipiens, and $R$. sphenocephala, all from the United States. 
Travassos (1930) argues that Rhabdias ranae Walton, 1929, is in reality Rhabdias entomelas (Leidy, 1851) Travassos, 1930. The original description by Leidy might refer to any species of the genus Rhabdias, and since there are several species reported from the United States it seems impossible to determine which one of these Leidy might have had at hand. It is evident that Leidy recognized that his form was not Rhabdias bufonis, but until better proof is offered, it can not be stated a priori that the first modern description of a species of Rhabdias other than R. bufonis from North American frogs must necessarily be a redescription of the Ascaris entomelas of Leidy, 1851.

6. Oswaldocruzia leidyi Travassos, 1917. From Pseudacris feriarum, Virginia, U.S.N.M. Helm. Coll. No. 19414. The other reported hosts are Bufo americanus and Hyla cinerea, both from the United States.

Steiner, G.

\section{REFERENCES}

1924. Some nemas from the alimentary tract of the Carolina tree frog (Hyla carolinensis Pennant). Journ. Parasitology, vol. 11, pp. 1-32, pls. $1-11$.

Travassos, Lauro.

1917. Trichostrongylinas brazileiras, Oswaldocruzia, n. gen. Brazil-Medico, vol. 31 , no. 9, p. 73 . Mar. 3.

1930. Pesquizas helminthologicas realisadas em Hamburgo VII. Notas sobre os Rhabdiasoidea Railliet, 1916. Mem. Inst. Oswaldo Cruz, vol. 24 , no. 3 , pp. 161-181, 42 figs.

Walton, A. C.

1929. Studies on some nematodes of North American frogs. I. Journ. Parasitology, vol. 15, pp. 227-240, pls. 16-20.

1930. Studies on some nematodes of North American Amphibia. II. Cryptobranchidae. Journ. Parasitology, vol. 19, pp. 20-24, 1 pl.

1931. A new parasite of Philippine Amphibia. Philippine Journ. Sci., 1931, pp. 351-353, 1 fig. 


\section{$2 \mathrm{BHL}$ Biodiversity Heritage Library}

Walton, Arthur Calvin. 1933. "Two new nematodes, and notes on new findings of nematodes parasitic in Amphibia." Proceedings of the United States National Museum 82(2947), 1-5. https://doi.org/10.5479/si.00963801.82-2947.1.

View This Item Online: https://www.biodiversitylibrary.org/item/32567

DOI: https://doi.org/10.5479/si.00963801.82-2947.1

Permalink: https://www.biodiversitylibrary.org/partpdf/8983

\section{Holding Institution}

Smithsonian Libraries

\section{Sponsored by}

Smithsonian

\section{Copyright \& Reuse}

Copyright Status: NOT_IN_COPYRIGHT

Rights: https://www.biodiversitylibrary.org/permissions/

This document was created from content at the Biodiversity Heritage Library, the world's largest open access digital library for biodiversity literature and archives. Visit BHL at https://www.biodiversitylibrary.org. 